\title{
Correction to: Language assessment literacy: what do we need to learn, unlearn, and relearn?
}

\author{
Christine Coombe ${ }^{1}$, Hossein Vafadar $^{2}$ and Hassan Mohebbi ${ }^{3^{*}}$
}

\begin{tabular}{l}
\hline The original article can be found \\
online at https://doi.org/10.1186/ \\
s40468-020-00101-6. \\
${ }^{*}$ Correspondence: hassan. \\
mohebbi973@gmail.com \\
${ }^{3}$ European Knowledge \\
Development Institute, Ankara, \\
Turkey \\
Full list of author information is \\
available at the end of the article
\end{tabular}

available at the end of the article

\author{
Correction to: Lang Test Asia 10, 3 (2020) \\ https://doi.org/10.1186/s40468-020-00101-6
}

The authors regret to mention that after the online publication of our article (Coombe et al. 2020) in Language Testing in Asia, we found out that the paper by Levi and InbarLourie (2020) is not cited in the final version of the paper and in the relevant places as required. Also, some additional corrections should be made. As a result of this, we do apologize to Levi and Inbar-lourie, the readers, and the publisher for the oversight. The following corrections should be considered in the manuscript:

Page 1:

The correct sentence in the 1st paragraph in 'Introduction' section is:

Given this evident growth of new literacies, it should come as no surprise that assessment literacy began to appear as an early contribution to the general education literature.

Page 3:

The correct sentence in the 1st paragraph in 'Language assessment and language learning' section is:

Language learning is viewed as a transdisciplinary process within multilingual multicultural realities in this current globalization, and this process is largely affected by new genres as a result of technological innovations and affordances of the current era (Leung \& Scarino, 2016; Shohamy \& Or, 2017, as cited in Levi \& Inbar-Lourie, 2020).

The correct sentence in the 2nd paragraph in 'Language assessment and language learning' section is:

Since language learning possesses multifaceted modes and constructs, this requires corresponding assessment practices. In a considerable recent research study, Levi and InbarLourie (2020) investigated language assessment literacy thoroughly. They came up with the following main six assessment themes which reflect current language-learning constructs:

Page 7:

The correct subheading is:

Assessment training and other effective factors.

(c) The Author(s). 2020 Open Access This article is licensed under a Creative Commons Attribution 4.0 International License, which permits use, sharing, adaptation, distribution and reproduction in any medium or format, as long as you give appropriate credit to the original author(s) and the source, provide a link to the Creative Commons licence, and indicate if changes were made. The images or other third party material in this article are included in the article's Creative Commons licence, unless indicated otherwise in a credit line to the material. If material is not included in the article's Creative Commons licence and your intended use is not permitted by statutory regulation or exceeds the permitted use, you will need to obtain permission directly from the copyright holder. To view a copy of this licence, visit http://creativecommons.org/licenses/by/4.0/. 


\section{Page 14:}

The following references should be added to the References section:

Inbar-Lourie, O. (2008). Constructing a language assessment knowledge base: A focus on language assessment courses. Language Testing, 25(3), 385-402.

Levi, T., \& Inbar-Lourie, O. (2020). Assessment literacy or language assessment literacy: Learning from the teachers. Language Assessment Quarterly, 17(2), 168-182.

Author details

${ }^{1}$ Higher Colleges of Technology, Dubai, United Arab Emirates. ${ }^{2}$ Universiti Sains Malaysia (USM), George Town, Malaysia. ${ }^{3}$ European Knowledge Development Institute, Ankara, Turkey.

Published online: 13 October 2020

Reference

Coombe, C., Vafadar, H., \& Mohebbi, H. (2020). Language assessment literacy: what do we need to learn, unlearn, and relearn? Lang Test Asia, 10, 3 https://doi.org/10.1186/s40468-020-00101-6. 